Katarzyna Barańska

Uniwersytet Jagielloński

Wydział Zarządzania i Komunikacji Społecznej

Instytut Kultury

\title{
„0 powrót muzealnych kapci” - czyli wskazanie wybranych możliwości reagowania przez muzea na trendy zmian w środowisku naturalnym i otoczeniu kulturowym
}

W siódmym numerze ZWAM-u został zainicjowany nowy dział („Muzeum Reagujące”), który jest bardzo bliski piszącej te słowa, ale także Wszystkim Pozostałym Członkom Redakcji. Wychodząc z założenia, że muzea są przede wszystkim wychylone ku PRZYSZŁOŚCI (por. Barańska 2013: 93 i n.) uznaliśmy, że trzeba wyjść z zaklętego kręgu, w którym podstawowym przekazem jest myślenie, że muzea należy traktować wyłącznie jako instytucje zajmujące się PRZESZŁOŚCIĄ. To, co obecnie się dzieje, co jest ważne dla świata i ludzi i to TERAZ, powinno być traktowane jako swojego rodzaju wyzwanie dla pracy muzealnej. Pozostając w porządku powinności należy stwierdzić, że to właśnie teraźniejszość stanowi bezwzględnie obowiązujący obszar, w którym muzealnicy poruszają się w poszukiwaniu obiektów do rozbudowywania kolekcji, przygotowywania wystaw czy działań edukacyjnych. Imperatyw monitorowania trendów, myśli, nurtujących ludzi problemów — tych o wymiarze społecznym, ale także jednostkowym - wydaje się więc dla muzealników koniecznością i obowiązkowym obszarem ich twórczego, zawodowego myślenia i podejmowanych aktywności. Dzięki czujności i wrażliwości na ludzkie sprawy, 
na to, co dla ludzi ważne, muzea będą mogły uczestniczyć w ogólnospołecznym i kulturowym dialogu, staną się rzeczywiście instytucjami ważnymi i współtworzącymi rzeczywistość. Tylko dzięki temu będą mogły spełniać powinność służby, która zawarta jest w definicji ICOM (https://icom.museum/ en/resources/standards-guidelines/museum-definition, odczyt: 1.09.2021) i dzięki której w gruncie rzeczy utrzymują i w przyszłości utrzymają swoją rację bytu i uzasadnią potrzebę ich funkcjonowania i zasilania z publicznych środków, zarówno ekonomicznych, jak i symbolicznych. Jeżeli muzealnicy nie wyjdą spoza przysłowiowych szaf, to instytucje, w których oni pracują, staną się z punktu widzenia życia publicznego instytucjami zbędnymi i niemożliwymi do wspierania i zachowania. Trzymanie więc ręki na pulsie problematyki społecznej staje się w tym rozumieniu raison d'être instytucji tak bardzo przecież zasłużonych dla kultury.

W ubiegłym roku w ramach nowo powołanego działu w naszym czasopiśmie odnieśliśmy się więc do dwóch obszarów, które były treścią wielu nadchodzących informacji, komentarzy opinii i rozmów ludzi. Pierwszym tematem okazała się kwestia pandemii COVID-19. Wirus okazał się tym, co zorganizowało nasze życie społeczne, skanalizował nasze fobie i aktywności, stał się wyznacznikiem life style’u, siłą napędową podejmowanych działań, a także i hamulcem dla działań, z których musieliśmy rezygnować. W publicznym życiu naukowym i popularyzatorskim poświęcono bardzo wiele stron na opisywanie, dokumentowanie tego zjawiska. Instytucje naukowe, kulturalne, edukacyjne musiały się zmierzyć z wyzwaniami, które wyrosły wraz z wzrastającą zachorowalnością i śmiertelnością w wyniku ekspansji wirusa. Według Meriam-Webster Dictionary, najpopularniejszym słowem roku 2020 (a więc roku, w którym ukazał się poprzedni numer ZWAM...) była „pandemia” (https://edition.cnn.com/2020/11/30/us/word-of-the-year-pandemic-dictionarytrnd/index.html, odczyt 27.07.2021), nic więc dziwnego i zaskakującego, że niemal wszystkie podmioty podejmowały w sobie właściwy sposób tematykę związaną ze zjawiskiem, które zorganizowało nasze życie w ubiegłym roku. ZWAM nie ogłosił „tematu numeru”, nie staraliśmy się zobrazować w sposób możliwie wyczerpujący tego, co działo się w muzealnictwie światowym, europejskim, polskim w wyniku ataku koronawirusa. Giganci światowi, zajmujący się dokumentowaniem muzealnych aktywności w wymiarze globalnym, zrobili to o wiele pełniej i lepiej niż my moglibyśmy (por. przede wszystkim: https://icom.museum/en/news/follow-up-report-museums-covid-19, odczyt; 27.07.2021). W naszym Dziale zasygnalizowaliśmy jednak tę tematykę. 
Drugim zagadnieniem, na które chcieliśmy zareagować choćby w symboliczny sposób, co do którego byliśmy i jesteśmy przekonani, że zasługuje na baczną uwagę oraz podejmowanie aktywności muzealnych wszelkiego rodzaju był (i jest) temat społeczności LGBTQIA i działań, które w tym zakresie mogą/powinny być podejmowane. Jako wzór służyć może muzealnictwo i rozwiązania podejmowane w Australii, dlatego tekst o tym, jak to się tam robi i jakie obwiązują zasady, uznaliśmy jako istotny. Drugi tekst dotyczył historii i współczesności polskiego przykładu muzeum poświęconemu tematyce społeczności LGBTQIA, który chcieliśmy przedstawić czytelnikom. Mieliśmy nadzieję, że pobudzimy naszych czytelników do myślenia i dyskusji, niestety jak do tej pory nie dostaliśmy żadnych informacji zwrotnych w postaci polemik, listów do redakcji czy artykułów w omawianych tu zakresach.

Nie oznacza to jednak, że „młyny nie mielą” i wierząc w to, że - być może - nasze teksty jednak trafiły na grunt podatny intelektualnie i żyzny, także w tym numerze podejmujemy jakże aktualny i wszechobecny w mediach temat zmian klimatycznych i tego, w jaki sposób ludzie mogą i muszą ustosunkować się do tego, co dzieje się w środowisku, którego już chyba nie sposób nazywać „naturalnym”. Antropocen stał się faktem nieodwracalnym (Żabicki, odczyt 10.08.2021), dlatego najlepiej będzie chyba rozszerzyć myślenie i mówić o środowisku „naturakulturowym”. Wpływ człowieka na to, w jaki sposób zmienia się klimat, środowisko geologiczne czy przyrodnicze we wszystkich jego obszarach jest nie do przecenienia i od dawna nie można go oceniać jako zrównoważonego. Można i należy jednak do owej równowagi dążyć, „zrównoważony rozwój” jest więc tu postulatem koniecznym i niezbędnym do realizacji. I realizacja ta nie może być kwestią przyszłości, ale jest wymogiem chwili obecnej i owego wspominanego na początku tego tekstu TERAZ. Muzealnicy, których przecież w zbiorze ludzi na ziemi jest zaledwie garstka, powinni więc traktować konieczność zajmowania się kwestią klimatu nie tylko jako obszar namysłu teoretycznego, ale także jako wyzwanie do podejmowania praktyk dnia codziennego.

$\mathrm{Na}$ temat tego, w jaki sposób instytucje kultury, w tym i muzea mogą przyczynić się do odwrócenia trendów zmian klimatycznych, pisze się coraz więcej. W polskim piśmiennictwie na uwagę zasługują opracowania Joanny Tabaki, obecne także i w innych tekstach w obecnym numerze ZWAM. W ubiegłym, 2020 roku, Autorka wydała dwie monografie dostępne w formacie pdf na stronie internetowej (https://www.joannatabaka.pl/ 
publikacje, odczyt 17.08.2021). W opracowaniu Zielona instytucja kultury. O stawaniu się miejscem kultury przyjaznym naturze Autorka wskazuje konkretne propozycje rozwiązań w zakresach oszczędzania zużywających się surowców, produktów oraz energii koniecznej do produkcji i podejmowanych aktywności. Nie zajmuje się tu w żaden szczególny sposób instytucjami muzealnymi, jednakże pojawiają się one jako egzemplifikacja niektórych propozycji.

Z kolei praca Kultura naturze, z Syrenka $w$ tle. Dobre praktyki proekologiczne w warszawskich instytucjach kultury podejmuje tematykę tworzenia takich sposobów funkcjonowania instytucji kultury, które zagwarantują, że będą one dążyć do zminimalizowania skutków zatruwania środowiska i wskażą ścieżki, którymi mogą podążać te instytucje, które chciałyby działać proekologicznie i inspirować innych do podejmowania tego trudu. Tabaka omawia różnorodne warszawskie instytucje, zarówno domy kultury, jak i teatry, odnosi się także do dwóch muzeów: Muzeum Historii Żydów Polskich POLIN oraz Muzeum Pałacu Króla Jana III w Wilanowie. Przedstawione tu zostały takie praktyki, które ograniczają zużycie papieru (elektroniczny obieg dokumentów, używanie makulatury do druku, rezygnacja z druków promocyjnych), wody (używanie kranówki do picia), energii (oświetlenie energooszczędne, zakaz dogrzewania pomieszczeń), a także segregacja i powtórne wykorzystywanie śmieci oraz zużytego etalażu. Muzeum w Wilanowie mając pod opieką Rezerwat Przyrody „Morysin” i park, podejmuje również aktywności związane bezpośrednio ze środowiskiem przyrodniczym tworząc przestrzeń edukacji i rekreacji (https://www.wilanow-palac.pl/co_mozna_zobaczyc_w_parku.html, odczyt: 17.08.2021), a także uczestniczy aktywnie w konsultacjach dotyczących rozwoju lokalnego i sposobów zagospodarowania przestrzeni.

Wszystkie te działania są ze wszech miar słuszne i należy je podejmować, a wobec alarmującego stanu klimatu opisywanego w najnowszym raporcie przygotowanym przez Międzyrządowy Zespół do spraw Zmiany Klimatu (IPCC), który ukazał się w sierpniu bieżącego roku, takie działania należy traktować jako bezwzględnie obowiązujący imperatyw (https://www.terazsrodowisko.pl/aktualnosci/raport-IPCC-2021-zmiany-klimatu-10704.html, odczyt: 16.08.21). Podejmowanie nawet najdrobniejszych aktywności w tym zakresie ma na pewno znaczenie, jednakże w doniesieniach medialnych i komentarzach ekspertów (licznych i wszechobecnych w rozmaitych mediach, ocierających się w tej chwili o tzw. „,wiedzę potoczną”) można odczy- 
tać przekonanie, że najważniejsze działania dla wstrzymania degradacji środowiska pozostają po stronie rządów i decydentów w sprawach emisji gazów. Dbałość o przeznaczenie do recyclingu butelek po wodzie pitnej czy innych opakowań z tworzyw sztucznych pozostawiana jest po stronie indywidualnych użytkowników, jednakże przypomina to raczej próbę atakowania słonia przez muchę. Zmasowany jednak atak drobnych działań może być elementem spowalniającym napływające zagrożenie, budującym ekologiczną świadomość i tym samym wspieranie tych politycznych decyzji, które mogą mieć pozytywny wpływ na środowisko. Dotyczy to zarówno jednostek, jak i organizacji, w tym oczywiście muzeów.

Działania opisywane przez Joannę Tabakę mogą być rozszerzone o aktywności podejmowane na poziomie decyzji organizacyjnych chociażby poprzez tworzenie infrastruktury budynków muzealnych, które na poziomie projektowania oraz adaptacji tych już istniejących poprzez oszczędności energii czy stosowanie jej alternatywnych źródeł mogą również wywierać wpływ na polepszenie sytuacji związanej z zatrzymaniem globalnego ocieplenia. Tego typu działania zalecają Autorki opracowania The Green Museum, które uważają, że muzeum funkcjonujące jako „zielone” jest powinnością, która wynika z misji instytucji, jest sposobem na oszczędność pieniędzy i ma wymiar edukacyjny poprzez wywieranie wpływu zarówno na pracowników, jak i na otoczenie, by propagować wprowadzanie zasad ekologicznych także w ich życiu prywatnym (Brophy, Wylie 2008: s. 1-4). Opracowanie autorek jest ilustrowane przykładami z muzeów amerykańskich, których praktyki nie zawsze są możliwe do przetransponowania na grunt europejski, w tym polski. Wynika to z odmienności systemu organizowania, finansowania, funkcjonowania instytucji muzealnych w różnych obszarach geograficznych i kulturowych, związanego z bardzo różnymi tradycjami i historiami poszczególnych krajów. Jednakże przynajmniej w jednym zakresie można wskazać pole wspólne, bardzo intensywnie zresztą eksploatowane i przez wielu uważane za najbardziej priorytetową współcześnie aktywność muzeów. Chodzi o podejmowanie działalności edukacyjnej.

W maju 2021, w związku z sytuacja pandemiczną w Polsce, drogą internetową zostały wykonane mini-badania rekonesansowe dotyczące przede wszystkim sklepików muzealnych. Do studentów (przyszłych menedżerów kultury z dwóch polskich uczelni), użytkowników kultury oraz muzealników została rozesłana ankieta z kilkoma pytaniami otwartymi 
z prośbą o ich swobodne wypowiedzi w obszarach zdefiniowanych przez piszącą te słowa. Blisko sto osób zechciało wypowiedzieć się na określone w kwestionariuszu pytania. Oczywiście nie należy traktować tej grupy jako reprezentatywnej, a uzyskane odpowiedzi są jedynie bardzo wstępnym rozpoznaniem terenu badawczego, który wymagałby pogłębionych i wyczerpujących eksploracji.

Z założenia głównym tematem ankiety były sklepiki muzealne. Ich obecność w bodaj każdym muzeum w ciągu ostatnich lat stała się faktem. Nawet jeśli poszczególne muzea nie mają wydzielonej przestrzeni, którą należałoby określić jako sklepik, w kasach biletowych umieszczany jest coraz szerszy asortyment produktów, które kojarzą się z konkretnym muzeum lub tematyką w nim reprezentowaną i są przeznaczone do sprzedaży dla zwiedzających.

Zapewne po części zostało to spowodowane faktem otwarcia się na światowe trendy muzealnictwa, które stały się bardzo dostępne wraz z rozwojem masowej turystyki oraz Internetu. Z drugiej strony należy podkreślić, co zresztą czynią zdecydowanie respondenci przeprowadzonej ankiety, że sklepiki i sprzedaż w muzeach stają się sposobem do polepszenia finansów muzeów. Ten ostatni aspekt był szczególnie podkreślany przez Respondentów, którzy postrzegają sklepik jako niezbędnie funkcjonujący element muzealnej codzienności i podkreślają, że sklepiki są potrzebne i „powinny istnieć...” ponieważ sprawiają, że „...przeciętny turysta ma możliwość przenieść $k a-$ watek kultury tradycyjnej do swojego domu, w swoją prywatną przestrzeń”, można obdarować „,bliskich” pamiątkami, które uznawane są za prestiżowe (Kotlerowie 426). Wsparcie finansowe, które dzięki zakupom w sklepiku może pozyskać muzeum, jest — jak podkreślają badacze problemu — również intencjonalną chęcią ze strony zwiedzających, by wesprzeć instytucję, którą uważa się za wartościową i godną wsparcia (Kotlerowie, tamże). Sklepiki podtrzymują także naturalną potrzebę konsumpcjonizmu, tak bardzo rozpowszechnioną współcześnie, a z kolei młodzi ludzie — studenci kierunków związanych z zarządzaniem kulturą podkreślają rezygnację z zakupów pamiątek muzealnych, co jest spowodowane ich przeważnie wysoką ceną, ale także coraz bardziej obecnym trendem minimalizmu w życiu codziennym. Sklepiki muzealne zasługują na szersze badania i pogłębione analizy w ramach interdyscyplinarnych badań, przekracza

\footnotetext{
${ }^{1}$ Wszystkie cytaty pochodzą z przeprowadzonych badań. Materiały w dyspozycji autorki, pozostają anonimowe.
} 
to jednak główny temat tego eseju, którego przyczynkarski charakter ma być jedynie próbą zasygnalizowania problemu i dostrzeżenia związków pomiędzy klimatem, a różnymi obszarami działalności muzealnej.

Może się wydawać, że przedmioty, które sprzedawane są w sklepikach nie stanowią ważnego aspektu powiększenia śladu węglowego, obniżania poziomu wód czy podnoszenia średniej temperatury. Powyżej wspomniane obszary dotyczące budynków, sposobu ogrzewania i oświetlenia produkują o wiele większe zagrożenie dla klimatu i na zarządzających spada odpowiedzialność za prawidłowe decyzje w tym zakresie prowadzące do wniesienia wkładu w ratowanie planety. Gadżety muzealne jednak są pewnego rodzaju mediatorem pomiędzy muzeum, sztuką (czy historią) tam prezentowaną, muzealnikami i zwiedzającymi, pomiędzy pokoleniami, są tym, co buduje relacje i tworzy nowe jakości życia i funkcjonowania w świecie.

Istotną inspiracją do spojrzenia na przedmioty sprzedawane w muzealnych sklepikach w odniesieniu do kryzysu klimatycznego była ostatnio wydana w Polsce książka Christiany Figueres i Toma Rivett-Carnaca Przyszłość zależy od nas. Przewodnik po kryzysie klimatycznym dla niepoprawnych optymistów (Figueres, Rivett-Carnac 2021). Autorzy, którzy zostali nazwani „Architektami Porozumienia Paryskiego 2015”, wskazują dziesięć ścieżek, którymi należy podążać, by „stworzyć przyszłość opartą na odnowie” tworząc świat, w którym oddawanie do atmosfery gazów cieplarnianych zostanie zminimalizowane, a osiągnięcie tego celu wymaga „dziesiątek mikrorozwiązań” (Figueres, Rivett-Carnac 2021:110). Inspirujące były również wspomniane opracowania Joanny Tabaki i jej zaangażowanie wyrażane zarówno w rozmaitych mediach (np. https://www.facebook.com/joanna.tabaka), jak i w czasie wystąpień konferencyjnych i rozmów prywatnych.

Owe „mikrorozwiązania” wskazane przez Figuerees i Rivett-Carnaca podzielone zostało na dziesięć działań, co do których Autorzy proponują wybrać jeden lub dwa i na podejmowaniu tego rodzaju aktywności i decyzji, które mają być wstępem do „zrobienia tego, co konieczne” (Figueres, Rivett-Carnac 2021:114). Muzea są jednym z miejsc, gdzie takie kroki mogą być podejmowane, a zastosowanie takiego myślenia do gadżetów w sklepikach jest rzeczywiście „micro” rozwiązaniem, ale może być jednym z tych (pochodzących z chińskiego przysłowia) „pierwszych kroków”, od których rozpoczyna się „najdalsza podróż”. Proponowane w tym eseju sposoby podążania za myślą Autorów i próba przystosowania ich postulatów do muzeów mogą (być może) stać się inspiracją do myślenia, które byłoby 
wskazówką do tego, jak uratować świat i uczynić go lepszym miejscem do życia. Nie chodzi tu zresztą o wskazanie konkretnych rozwiązań, na poszukiwaniu niezaprzeczalnych prawd i reakcji na problemy ekologiczne, a jedynie na wyeksponowanie niektórych możliwości potraktowania tematu, budowania takiego rodzaju środowiska muzealnego, w którym poszukiwanie odpowiedzi na rzadko zadawane na co dzień pytania jest wyzwaniem właściwym i kulturowo płodnym. W tym sformułowaniu ma się mieścić głębokie przekonanie o relacjach, które mogą być negocjowane w obszarze zwanym „naturakultura” i o tym, że chociaż granice pomiędzy naturą i kulturą są coraz mniej wyraźne i zacierające się, to jednak w ludzkiej świadomości są ciągle jeszcze obecne i dające możliwość tworzenia regulacji wpływających na przebieg wydarzeń.

O tym, że należy kierować myślenie także w tym kierunku przekonują również uzyskane w ankietach odpowiedzi na zadane tam wprost pytanie o związki pomiędzy gadżetami i zmianami klimatycznymi. Większość Respondentów ze wszystkich trzech grup nie dostrzega takiego związku i wyraziło to w odpowiedziach (najczęściej) sformułowaniem „BRAK” lub przedstawieniem graficznym: ,...”. Postrzeganie muzealnych gadżetów w kategoriach współzależności z klimatem obecne było najbardziej w ankietach, których nadawcami byli studenci. To oni wskazywali na konsekwencje sprzedaży pamiątek jako „marnowanie zasobów”, „produkowanie i kumulację śmieci”, szczególnie powiększanie śladu węglowego w przypadku „transportu z Chin” produkowanych tam przedmiotów, a można tu także odnaleźć lakoniczne stwierdzenia, że „kupowanie zbędnych przedmiotów nie ratuje naszej planety”, „produkcja czegokolwiek szkodzi”, a sprzedaż pamiątek z wystawy w Tate Modern ,... Shapes of Decay: A Discussion about Art and Ecology, której narracja jest skupiona wokół sposobów rozumienia ekologiczności, problemów zmian klimatycznych itp.” nazwane jest „swego rodzaju hipokryzją". Dostrzeganie problemu przez ludzi młodych można traktować jako dobry znak, jednakże z doniesień prasowych, a być może przede wszystkim ze wspomnianego Raportu IPCC, wynika jasno, że świat nie ma czasu, by czekać na ich decyzyjność, jeśli ludzkość i jej miejsce do życia mają być uratowane.

Pierwsze dwa działania wskazane przez Autorów omawianej książki (Figueres, Rivett-Carnac 2021: 115-124) dotyczą tego, w jaki sposób ludzie powinni regulować swój stosunek do czasu, do przeszłości oraz przyszłości i według tego jak tworzyć realia, które umożliwią, że przyszłość podąży 
w pożądanym kierunku, dającym możliwości rozwoju życia. Stwierdzenie o konieczności „złożenia hołdu przeszłości” jest zapewne do zastosowania jako niemal uniwersalna formuła określająca muzeum. Bez potrzeby dokumentowania można uznać, że myślenie o muzeach jako obszarze kulturowym nastawionym na składaniu hołdu przeszłości jest obecne i czytelne zarówno w literaturze przedmiotu, jaki w innych, potocznych i powszechnych obszarach kulturowych wypowiedzi. Figueres i Rivett-Carnac jednak wskazują kolejny krok, który musi być zrobiony, który wymaga „uwolnienia się od przeszłości” i „uodpornienia się na nostalgię” (s. 115). Czy można pomyśleć o muzeach jako uwalniających się od przeszłości? Czy można wyobrazić sobie taką instytucję, która wprawdzie korzysta z zasobów z przeszłości się wywodzących, ale jest przede wszystkim nastawiona na myślenie o tym, jaki świat kształtuje, o przyszłości? O tym, że dziedzictwo, które zachowujemy w muzeach ma na celu przede wszystkim realizację przenoszenia istotnych treści i przekazywania ich następującym pokoleniom? Czy dotyczy to także - przedmiotów w muzealnych sklepikach?

W przeprowadzonych badaniach wskazane zostało jasno, że najczęściej gadżety w sklepikach kupowane są jako pamiątki stanowiące udokumentowanie wizyty w prestiżowym muzeum, „chęć pochwalenia się odwiedzeniem jakiegoś miejsca”, „snobizmu na dane miejsce”, zaś wypowiedź najbardziej bezpośrednia zawiera stwierdzenie, że „głównym celem jest pokazanie się jako osoba po prostu kulturalna, pod pewnym względem z wyższych sfer”. Respondentka wskazuje, że osoby starające się dokonywać zakupów dla podsycenia własnego snobizmu i prestiżu najchętniej sięgają po torebki płócienne z nadrukiem obrazu — lub inne „widoczne” gadżety — które „aż krzyczą: patrzcie jacy jesteśmy kulturalni i awangardowi! Na temat zachowania takich grup można by było napisać całą pracę, dlatego skrócę to tylko do stwierdzenia, że takie grupy kupują tego typu gadżety aby wykreować pewien wizerunek, raczej niż z faktycznego zainteresowania tematem”. Takie stwierdzenie jest kolejnym dowodem na konieczność, którą muzealnicy niekiedy zdają się pomijać, a mianowicie wymóg znajomości aktualnie obowiązujących trendów, mód kulturalnych, znajomość otoczenia (nie tylko) społeczno-kulturowego i tego, co w danym momencie jest znakiem prestiżu i podsyca ludzką potrzebę snobizmu i bycia en vogue.

Przedmioty kupowane w sklepikach są materialnym wyrazem pamięci i nośnikiem wartości istotnych dla odbiorców, które są na tyle istotne, że obiekty te wypełniają funkcje edukacyjne, „w jakimś zakresie dopełniają 
misyjne działania Muzeum w zakresie edukacji kulturalnej, promowania wszystkich ważnych dla nas haseł, idei”. Specjalista od marketingu kulturalnego potwierdza takie intuicje stwierdzając, że obecnie „muzea nie są w stanie wykorzystać marketingu do tego, czym jest dzisiaj jako narzędzia do analizy i sposobu działania, służącemu osiąganiu wyznaczonych sobie celów” (Tobelem 1998: 339 za: Chhabra 2010: 85).

Jedna z osób odpowiadających na rozesłany zestaw pytań podkreśliła również dążność do posiadania „małego elementu, który będzie przypominał mi o tym miejscu”, w którym to stwierdzeniu jest dość wyraźnie zawarta antycypacja czasu, który nadchodzi i wiara, że właśnie w przyszłości będzie się chciało wracać do wspomnień oraz, że będą one ważne; „ewentualnie kupiona pamiątka miałaby na celu zachęcenie mnie do odwiedzania takich miejsc w przyszłości”.

Czy zostało jednak sformułowane cokolwiek na temat tego, co powinno być owym przedmiotem pamięci? W jaki sposób można w muzealnym sklepiku przedłożyć ofertę handlową, która spełni cele ekonomiczne, edukacyjne, kulturowe równocześnie wychylając się ku przyszłości i otwierając się na działanie drugie wskazane przez Figueres i Rivett-Carnaca (s.120) zakładające, że należy mieć „... jasną wizję przyszłości”. Autorzy wskazują konkretne ścieżki myślenia/funkcjonowania, którymi należy się kierować. Na uwagę zasługują na pewno: „zaczynanie od kwestionowania” i budowanie na silnych fundamentach — „wyobraźnia to podstawa” oraz postulat uważności „na to, co nadchodzi” (s. 124). Muzea są instytucjami, które budują swój potencjał w oparciu o naukę, należy tu więc postulować badania społeczne, kulturowe i marketingowe, które definiując okoliczności tkwiące w otoczeniu pomogą w utworzeniu odpowiedniej oferty.

Jednym z trendów wszechobecnych we współczesnym świecie jest wspomniany wyżej konsumpcjonizm, a wielu Respondentów wskazywało właśnie to zjawisko jako przyczynę dokonywania zakupów w sklepikach. Niektórzy podkreślają, że chociaż w muzeach „są rzeczy bardziej wyrafinowane niż np. w Sukiennicach, więc lepiej kształtują gusty...”, a ich posiadanie ma głębsze znaczenie (estetyczne, sentymentalne itp.), to jednak „kupowanie jest wypełnieniem potrzeby miecia na własności”, a „wiele osób kupuje też rzeczy na targach z byle czym, po prostu trzeba coś kupić”. Bardzo dobitnie wyraził to Papież Franciszek w proekologicznej Encyklice „Laudato si”, która w myśleniu o zmianach klimatycznych i działaniach im zapobiegających ma dla katolików (czyli wielu ze zwiedzających muzea w Polsce) istotne znacze- 
nie aksjologiczne: „... wszyscy uważają się za wolnych, dopóki zachowują rzekomą wolność konsumowania” przestrzegając, że „obsesja na tle konsumpcyjnego stylu życia, zwłaszcza gdy bardzo niewielu jest w stanie tak żyć, może sprowokować jedynie przemoc i wzajemne zniszczenie” i nawołuje do „nawrócenia ekologicznego” (Franciszek 2015:176-177). Franciszek wychodzi z pozycji wynikających z wiary religijnej, z kolei Figueres i Rivett-Carnac, myśląc w duchu obywatelskości, wskazują kolejne działanie na rzecz nadania zmianom klimatu pożądanego kierunku — dostrzeżenie „w sobie obywateli i obywatelki, nie zaś konsumentów” (Figueres, Rivett-Carnac 2021:133) i starają się argumentować przekonując, że „nabywanie przedmiotów nie w celu zaspokajania realnych potrzeb, ale dla samej satysfakcji i poczucia przynależności jest uzależniające, prowadzi też do kwestionowania naszej wartości i wywołuje zamęt w obszarach takich jak tożsamość czy życiowe cele” (Figueres, Rivett-Carnac 2021:136). To stwierdzenie jest dokładnym zaprzeczeniem misji, które pełnione są przez muzea i realizowane poprzez dążenie do osiągania celów wyznaczanych w dokumentach założycielskich i strategicznych. Budowanie i wzmacnianie tożsamości lokalnej, regionalnej czy narodowej, myślenie według wartości, stanowienie obszaru wymiany myśli i negocjowania znaczeń kultury współczesnej są wymieniane i odmieniane na różne sposoby jako te sfery, w których muzea powinny funkcjonować w zgodzie z współczesnymi wymogami. Jak wskazują Autorzy przytaczanej książki, należy zredefiniować pojęcie „dobrego życia” i uwolnić się od jego konsumpcyjnego modelu. Sklepik muzealny okazuje się koniecznością, która równocześnie w pewnym, wspomnianym powyżej sensie, stanowi zaprzeczenie misji muzeum. Ale przecież nie można „obrażać się” na potrzeby otoczenia i stawać do nich tyłem, próbując równocześnie narzucić własną wizję świata i własne sposoby realizacji tej wizji. Poza tym muzealnicy podkreślają korzyści ekonomiczne wynikające z funkcjonowania sklepików i sprzedaży w nich przedmiotów poprzez rozwiązania, które mogą być do zastosowania w sklepikach muzealnych. Postulują oni bowiem: „Konsumujcie w lepszy sposób” i „Stawiajcie na dematerializacje” (Figueres, Rivett-Carnac 2021:137 i n.).

Pierwsza z tych wskazówek polegać ma na tym, by stawiać na jakość produktu zamiast na ilość oraz dążyć do korzystania z usług firm, które „postawiły na zrównoważoną produkcję i należą do organizacji pilnujących przestrzegania norm” (s. 137). Muzea mają wszak w tym zakresie dosyć duże doświadczenie i jakość muzealnych produktów jest postrzegana jako 
główne kryterium zakupu muzealnych suwenirów, wskazują na to sami respondenci: „wszystkie pamiątki cechują staranność i estetyka wykonania oraz walory artystyczne”. Poza walorami estetycznymi zwraca się również uwagę na unikatowość, traktuje się to kryterium jako wyjątkową okazję, „bo podobnych gadżetów nie znalazłabym w sklepiku w Polsce”. Dla wielu osób istotna była także użytkowość pamiątek, chociaż niektórzy w krytyczny sposób postrzegali sprzedawanie w sklepikach przedmiotów, „z których korzystamy codziennie i które w związku z tym już posiadamy, a które w tego typu muzeach oklejane są reprodukcjami, czy logo muzeów” i są rzeczami „na jedno kopyto w każdej placówce muzealnej. Np. taki sam ołówek tylko z innym napisem”. Równocześnie trzeba przypomnieć, że jakość pamiątek muzealnych jest bardzo często przyczyną ich wysokiej ceny, a to z kolei wskazywane było przez Respondentów ankiety jako przyczyna rezygnacji z dokonywania zakupów (szczególnie w grupie studentów, co wydaje się oczywiste).

Należy tu również zwrócić uwagę, że kryteria dokonywania zakupów lub rezygnacji z nich są podyktowane najczęściej bardzo indywidualnymi preferencjami, bez eksplikowania świadomości obywatelskiej odpowiedzialności w kwestiach klimatu, zrównoważonego rozwoju lub ruchu fair trade. Reprezentatywną wypowiedź jednej z respondentek, że „nigdy nie śledziłam skąd pochodzi kartka pocztowa, czy długopis, które kupiłam w sklepiku muzealnym” okraszona została wyznaniem, iż „domyślam się, że nie są to lokalnie produkowane zawsze w sposób humanitarny produkty”. Optymizmem napawa to, że nawet przy opracowywaniu wyników z przeprowadzonych badań rekonesansowych można było odnieść wrażenie, że samo zadanie pytania o relacje pomiędzy ruchem fair trade a muzeami stawało się otwierające na myślenie i poczucie odpowiedzialności. Ankietowani wypowiadali się w duchu, który reprezentuje przekonanie, że „nie należy likwidować sklepów muzealnych, ale zmienić ich standardy i ofertę”.

Można tu, idąc także tropem wskazywanym przez muzealników, studentów i zwiedzających różnych zawodów, proponować rozwiązania, które wprawdzie nie zlikwidują zupełnie zagrożeń klimatycznych, ale w zakresie unikania niezrównoważonego rozwoju czy unfair trade mogą stać się mikrorozwiązaniem, które w ostatecznym rozrachunku mogą okazać się rozwiązaniem w skali mezo, a nawet makro.

Respondenci zwracają bowiem uwagę na to, by w sklepikach sprzedawane były pamiątki wykonywane najchętniej „z surowców naturalnych: glina, 
drewno, słoma, wiklina, korzeń sosny, a także tkanina, nić, papier i metal”, powinny być wykonane „z materiałów nieszkodzących środowisku”, „dobrze, żeby pochodziły z recyclingu”. Wiele wypowiedzi respondentów dotyczyło, niekoniecznie explicite, konieczności dbania o to, by sprzedawane rzeczy w muzealnych sklepikach nie powiększały puli śmieci, postrzegając zresztą recycling i użytkowość jako sposoby radzenia sobie z problemem nadmiaru odpadów, który stał się jedną z przyczyn przezywanego obecnie kryzysu ekologicznego. Zygmunt Bauman w wydanej w 2004 roku pracy „Życie na przemiał” (Bauman 2004) skupia swoją uwagę socjologa przede wszystkim na sprawach ludzi i społeczeństwa. Jednakże rozpoczyna rzecz od zrelacjonowania literackiej wizji Itala Calvina z Niewidzialnych miast, w której autor roztacza wizję jednego z miast, Leonii, jako miejsca, którego mieszkańcy codziennie używają „nowych i odmiennych przedmiotów”, stare zaś tworzą otaczające miasto góry, które przy odpowiednim wietrze zatruwają powietrze centrum i „świeżutkie, lśniące i zalotnie pachnące wnętrza eleganckich sklepów" (Bauman 2004:8). Zygmunt Bauman kreśląc wizję świata poprzez pryzmat odrzutów i śmieci antycypował rzeczywistość, która wtedy nie była tak wyrazista, a dziś, kilka lat po śmierci Socjologa, stała się przerażającym udziałem nas wszystkich i przed którą zdają się ostrzegać głosy tych, którzy chcieliby by gadżety muzealne nie powiększały puli śmieci. Należy tu jednak zwrócić uwagę na aspekt zawarty w wypowiedzi jednej z pracownic muzeów, która wyznała: „od lat buszuję w second-handach i bardzo rzadko spotykam muzealne gadżety. Może się ich nie wyrzuca?”. Pisząca te słowa z kolei widywała wielekroć „muzealne gadżety” na rozmaitych jarmarkach i targach staroci. Może sam fakt pochodzenia z muzeum i opatrzenie ich muzealnymi inskrypcjami je nobilituje i obdarza „patyną starości” tak chętnie nabywaną, nie tylko przez muzealników? Wypowiedź jednego z akademików, którzy również wzięli udział w ankiecie, potwierdza taką myśl: „... nie lubię gromadzić rzeczy, z wyjątkiem... wyjątkowych: starych, rzadkich”, a o gadżetach w muzeach stwierdza, że „...powinny bardziej wyróżniać się swoją wyjątkowością (jak wyjątkowe jest muzeum)”.

Taką cechę mogą zapewnić praktyki wskazywane dość często przez respondentów, w których stwierdza się, że sklepiki muzealne powinny sprzedawać asortyment pochodzący od lokalnych twórców i artystów. Równocześnie popieranie lokalnych producentów może stanowić „możliwość (ich) wsparcia”, „warto promować lokalne rękodzieło”, dzieje się 
to przecież z korzyścią dla kultury danej miejscowości czy regionu. Jedna ze studentek zarządzania kulturą, która wprawdzie określiła się jako osoba, która nie kupuje pamiątek głównie ze względu na zaporowe ceny, oświadcza nawet: ,jeśli dodatkowo są one projektowane i produkowane specjalnie dla określonej instytucji lub są to wyroby regionalne, to jestem jak najbardziej na tak” i argumentuje to szerzej: „(M)yślę, że produkowane lokalnie pamiątki mają wiele zalet, zarówno dla instytucji, jak i wykonawcy. Mają one swój indywidualny charakter, wywołują pewne emocje w odbiorcy oraz promują lokalną kulturę. Ręczna robota w duchu ekologii oraz angażowanie lokalnej społeczności w życie instytucji, idealnie wpisuje się w koncepcję społecznej odpowiedzialności biznesu (CSR). Dodatkowo, produkty oferowane w sklepikach mogą urozmaicić ofertę muzeum oraz zachęcić odbiorców do wybrania danej instytucji”. Zwrócenie uwagi na podnoszenie przedsiębiorczości i wpływ na gospodarkę danego regionu obecne było w wypowiedziach osób zwiedzających muzea, a nie związanych z nimi profesjonalnie. Poza ekonomicznym wsparciem samego muzeum należy przecież wspierać małe, lokalne biznesy lub producentów indywidualnych, co w efekcie przyczynia się do tego, by „wspierać polskie przedsiębiorstwa”. Równocześnie - co wszak jest także postulowane przez Figueres i Rivett-Carnaca — chodzi tu o przestrzeganie norm, czyli poszerzenie myślenia w kierunku funkcjonowania w obszarze fair trade. Jak podkreśla znawczyni problemu, Katarzyna Wasilik „dekonsumpcja (konsumpcja ograniczona), ekokonsumpcja, etnocentryzm konsumencki (preferowanie produktów krajowych, lokalnych) stają się alternatywą dla współczesnych konsumentów” (Wasilik 2015:102), zaś tytułowa odpowiedzialna konsumpcja oznacza „świadome dokonywanie decyzji zakupowych w oparciu o informacje dotyczące miejsca i sposobu produkcji danego towaru i wybór takich produktów, których wytworzenie nie wiązało się z łamaniem praw człowieka, degradacją środowiska czy cierpieniem zwierząt” (Wasilik 2015:103). Takie myślenie obecne jest coraz powszechniej wśród (szczególnie młodych) ludzi: ,gdybym zobaczyła oznaczenie fair trade na gadżecie muzealnym, z pewnością przekonałoby mnie to (jeszcze) bardziej do jego zakupu. Wydaje się, że sklepik muzealny to nie jest wielki rynek trudno jednak o nim zapomnieć, gdy myślimy o globalnym sprawiedliwym handlu i ilości przysłowiowej chińszczyzny, jaką w niektórych sklepikach możemy znaleźć. Myślę, że wzrost świadomości społecznej w tym zakresie powinien odbijać się także w takich przestrzeniach jak muzealne gadżety”. 
Odpowiedzialność w zakresie konsumpcji może oznaczać praktykowane przez Ruch Fair Trade „przyznawanie premii na rozwój na rzecz społeczności lokalnej” mającej ona na celu „poprawę warunków życia i rozwój poszczególnych regionów" (Wasilik 2015:106).

Ale postępowanie w tym duchu może również oznaczać działanie na rzecz ratowania klimatu poprzez realizację kolejnego postulatu Figueres i Rivett-Carnaca zdefiniowanego jako „Stawiajcie na dematerializację” (Figueres, Rivett-Carnaca 2021: 137 i n.). Oznacza to korzystanie z technologii, dzięki której możemy dziś „rezygnować z fizycznych przedmiotów, a jednocześnie cieszyć się tym, co nam dostarczają” (tamże). Uderza, że jest to wręcz modelowe opisanie tego, co w swojej specyfice oferują nam muzea! Czymże bowiem innym jest obcowanie z dziełami sztuki, czy obiektami na wystawach archeologicznych, historycznych czy etnograficznych? Krzysztof Pomian zwracał uwagę na wyłączenie obiektów muzealnych z obiegu gospodarczego, ekonomicznego czy utylitarnego (Pomian 2001:s. 19 i n.), czyli rezygnację z ich użycia w obiegu społecznym, przy równoczesnym budowanie sfery doświadczeń i wiedzy w trakcie zwiedzania wystaw muzealnych. Kwestia tego, że muzea są przestrzenią doświadczania, nie wymaga odniesień, można jednak podkreślić, że i Respondenci odnosili się właśnie do doświadczania wypowiadając się przecież na temat sklepików muzealnych: „Ludzie z zachwytem nad obiektami, miejscem, które odwiedzają i dobrze się w nim czują chcą zabrać tę cząstkę emocji, wzruszeń i wspomnienie dobrego czasu ze sobą (...) i dlatego chęć posiadania wycinka tej rzeczywistości”; „Ludzie chcą mieć pamiątki z ładnych i miłych miejsc, w których byli i w których coś przeżyli”; „Najważniejsze są przecież nasze wspomnienia i duchowo/intelektualne przeżycia z muzeum (...) Nie idę do instytucji, żeby nabywać kolejne rzeczy, idę zaspokoić swoje wyższe potrzeby”. Tak zwane „wyższe potrzeby” nie potrzebują wszak koniecznie „materialnego wyrazu”, nie jest to warunek sine qua non, by doświadczać i by zachowywać przeżycia, wspomnienia i bogactwo wartości i zasobów duchowych i intelektualnych wyniesionych z muzeum. Odmaterializowanie doświadczenia muzealnego jest więc kolejnym tropem, który jest lub może być realizowaniem misji muzeum stawiającego wszak na upowszechnianie celów wyższych. Odbywać się to może na różne sposoby. Poza wspomnianą przez Figueres i Rivett-Carnaca technologią, dzięki której można zachowywać wspomnienia, można wskazać na przykład organizowanie warsztatów, w czasie których rozpoznaje się techniki czy sposoby produkcji 
przedmiotów w muzeum, buduje relacje, ale również „fajnie by było, gdyby muzea organizowały warsztaty, podczas których można sobie samemu zrobić/namalować pamiątkę związaną z wystawą”, co słusznie podkreśla jeden z respondentów. Materia i jej użycie nie mogą i przecież nie znikną zupełnie, a chodzi o to, by zmienić styl konsumpcji, przynajmniej dopóki świat i jego klimat nie wrócą do równowagi (nawiasem mówiąc ciekawe, jak będzie nazwana ta epoka? Czy będzie to kolejny „holocen”?). Sklepiki stanowią swoisty bufor pomiędzy światami, z których jeden został opisany przez Zygmunta Baumana jako porównywalny do cmentarza i oderwany „od życiowego zgiełku, oddzielone od spraw codzienności we własnych, zamkniętych przestrzeniach”, gdzie nie wykonuje się życiowych czynności typu jedzenie, picie, dotykanie, nie pozwala dzieciom na nadmierny ruch (Bauman 2004:187). Sklepik oddziela tę przestrzeń od „scenerii codziennego życia (a - KB) ...imiona gry to kruchość i przemijanie” (tamże). Bauman zresztą konstatuje, że „wartości są wartościami, dopóki nadają się do natychmiastowej konsumpcji na miejscu. Wartości towarzyszą ulotnym doświadczeniom. Podobnie jak piękno” (Bauman, 2004:189). Kolejny to argument dla odchodzenia od produkowania śmieci, ergo: przyczynianie się do pogarszania jakości klimatu i tworzenia sytuacji, w której muzea po prostu przestaną istnieć. Wizje zamieszczane w literaturze i beletrystyce nie przewidują tego typu instytucji w świecie postapokalipsy. Lech M. Nijakowski w książce opisującej społeczeństwo w świecie postapokaliptycznym według wizji zamieszczonych w tekstach kultury popularnej podkreśla, że „apokalipsa jest także zagładą rzeczy. W starym świecie zapewniały nam wygodę i bezpieczeństwo (...) a rzeczy i żywność oczerniane bez taryfy ulgowej w starym świecie przez ekologów nagle stają się zbawieniem...” (Nijakowski 2018:261), ponieważ „funkcje wielu urządzeń przestają być już czytelne. Pozostałości starego świata wykorzystywane są w nowy sposób” (tamże, s. 231) i nie ma możliwości i przestrzeni do tego, by je wyłączać z obiegu użytkowego (Pomian), umieszczać na cmentarzu (Bauman), czy traktować jako „zbieraczki kurzu” (Respondentka w ankiecie).

Sklepiki stanowią najczęściej ostatnie ogniwo muzealnego łańcucha doświadczeń, ale stanowią część integralną muzeów. Powinny, jak chce jeden z Respondentów, z którym trzeba się zgodzić, stanowić i być traktowane jako „integralna część narracji muzealnej”. Pierwszym ogniwem w holocenowej rzeczywistości była szatnia, gdzie należało założyć tak obśmiewane i znienawidzone filcowe kapcie, które chroniły podłogi przed 
zanieczyszczeniem i zniszczeniem (szczególnie istotne przy zwiedzaniu przestrzeni gdzie zachowały się oryginalne posadzki — np. w Pałacu w Kozłówce). Kapcie stały się symbolem wstecznictwa muzealnego, zastąpione z ulgą plastikowymi, jednorazowymi ochraniaczami na buty. Dzisiaj, być może, z powodów, które wyłuszczone zostały w sygnalizującym zaledwie wymiarze powyżej, należy pomyśleć o pomyśle powrotu do jakiejś formy wielorazowych i podlegających ewentualnie recyklingowi ochraniaczy, które pomogą w ochronie podłóg, co przecież czasem bywa koniecznością. Może ochraniacze powinny być współwytwarzane przez gości w czasie warsztatów? W ten sposób myślenie według zasad mających na celu uratowanie świata przed zagładą klimatyczną spięłoby, jak klamrą, wszelkie działania muzealne podejmowane zarówno przez pracowników, jaki przez zwiedzających. To, co dzieje się wewnątrz tak wytworzonych granic wymaga szerszych opracowań, pogłębionych badań (których w tym przypadku nie dało się przeprowadzić z powodu pandemii), korzystania z doświadczeń specjalistów (jak chociażby cytowani tu i stanowiący swoistą, nie do końca wyeksplorowaną oś tego eseju Christina Figueres i Tom Rivett-Carnac) oraz dobrej woli i nadziei na to, że jesteśmy w stanie przyczynić się do ostatecznego zwycięstwa życia nad śmiercią. Ostatecznie przecież muzea powstałe jako przesłanie Przeszłości ku Przyszłości również powstały z taką myślą i taką nadzieją. Z nadzieją pozostajemy także i my. Nie tylko na uratowanie świata, ale także na to, że rozpoczynamy dyskusję, zamieszczamy w ZWAM teksty poświęcone temu zagadnieniu, licząc na odzew ze strony Naszych Szanownych Czytelników.

\section{Bibliografia}

\section{Barańska Katarzyna}

2013: Muzeum w sieci znaczeń. Zarządzanie z perspektywy nauk humanistycznych, Wydawnictwo Attyka, Kraków

\section{Bauman Zygmunt}

2004: Życie na przemiał, przeł. Tomasz Kunz, Wydawnictwo Literackie, Kraków

\section{Brophy S. Sarah, Wylie Elisabeth}

2008: The Green Museum. A Primer on Environmental Practice, AltaMira Press

\section{Chhabra Deepak}

2010: Sustainable Marketing of Cultural and Heritage Tourism, Routledge Critical Studies in Tourism, Business and Management

\section{Figueres Christiana, Tom Rivett-Carnac}

2021: Przyszłość zależy od nas. Przewodnik po kryzysie klimatycznym dla niepoprawnych optymistów, przeł. Aleksandra Szymczyk, Wydawnictwo Krytyki Politycznej 


\section{Franciszek}

2015: Encyklika LAUDATO SI’ Ojca Świętego Franciszka poświęcona trosce o wspólny dom, TUM Wydawnictwo Wrocławskiej Księgarni Archidiecezjalnej

\section{Nijakowski Lech M.}

2018: Świat po apokalipsie. Społeczeństwo w świetle postapokaliptycznych tekstów kultury popularnej, Wydawnictwo Naukowe Scholar, Warszawa

\section{Pomian Krzysztof}

2001: Z Zbieracze i osobliwości, Paryż - Wenecja, XVI - XVIII wiek, przeł. Andrzej Pieńkoś, Wydawnictwo UMCS, Lublin

\section{Sutton Sarah}

2020: The evolving responsibility of museum work in the time of climate change, Museum Management and Curatorship, VOL. 35, NO. 6 s. $618-635$

\section{Tobelem, J.}

1998: The Marketing Approach in Museums. Museum, Management and Curatorship, 16(4): 337-354, za: Chhabra Deepak, Sustainable Marketing of Cultural and Heritage Tourism, Routledge Critical Studies in Tourism, Business and Management, 2010

\section{Wasilik Katarzyna}

2015: Idea Fair Trade. W kierunku odpowiedzialnej konsumpcji, Problemy Zarządzania, Finansów i Marketingu, Zeszyty Naukowe Uniwersytetu Szczecińskiego, nr 38:2015 (865), DOI: 10.18276/pzfm.2015.38-10, s. 101-109

\section{Żabicki Piotr}

Ewolucja i antropocen. Pytania o człowieka, https://nauka.uj.edu.pl/aktualnosci/-/ journal_content/56_INSTANCE_Sz8leL0jYQen/74541952/135130073, odczyt:10.08.2021)

\section{Strony internetowe:}

https://www.joannatabaka.pl/publikacje, odczyt: 17.08.2021

https://www.wilanow-palac.pl/co_mozna_zobaczyc_w_parku.html, odczyt: 17.08.2021 https://www.teraz-srodowisko.pl/aktualnosci/raport-IPCC-2021-zmiany-klimatu-10704. html, odczyt:16.08.2021

https://icom.museum/en/resources/standards-guidelines/museum-definition, odczyt 1.09.2021

\section{Katarzyna Barańska}

\section{„For the return of museum slippers,” i.e. an indication of selected possibilities for museums to respond to trends in changes in the natural and cultural environment}

The IPCC Report on the Future of Climate Change, published in August 2021, leaves no doubt that everyone must work to reverse deadly trends. Museum institutions also share responsibility for the future of the planet, and their raison d'être also depends on it. Only 
a fragment of museum activities that are or may be undertaken in order to participate in saving the Earth is mentioned in the text. They concern the last and seemingly the least important link in museum activities - the shops and souvenirs offered there. The ways of thinking and organizing the sales of souvenirs were indicated, as well as arguments to counteract excessive consumerism, which was treated as the implementation of the mission and essence of museology.

Keywords: climate change, museum shop, consumption, cultural changes 
